УДК 343.9.01

DOI https://doi.org/10.32849/2663-5313/2020.3.44

\title{
Дмитро Хомич,
}

аспірант кафедри кримінального права і прочесу

Східноєвропейського національного університету імені Лесі Украйнки

\section{«СЛІДОВА КАРТИНА» ВИКРАДЕННЯ ПРИРОДНОГО ГАЗУ ШЛЯХОМ МАНІПУЛЯЦІЙ ІЗ ЛІЧИЛЬНИКОМ}

У статті проаналізовано виникнення терміна «слідова картина». Відмічено, що кожний злочин неминуче супроводжується виникненням «слідової картини». Ці «сліди» виявляютьвся певними змінами середовища. Існує певна зв'язаність прочесу злочину з іншими прочесами реальності. Зроблено висновок, що прочес злочину викликає зміни середовища, а вони, у свою чергу, інформують нас про наявність злочину. Вказано, що існує кілька точок зору на розуміння поняття «слідова картина».

Метою статті є вивчення і аналіз поняття «слідова картина» та опис типової «слідової картини» викрадання природного газу шляхом втручання в роботу приладів обліку.

Зазначимо, що сліди злочинів класифікуються за різними критеріями. У статті показано, що доиільно сліди викрадання природного газу шляхом втручання в роботу приладу обліку за способом їх вчинення об'єднати в декілька груп. Також обгрунтовано, що причини та умови викрадення природного газу шляхом втручання в роботу лічильника тісно пов'язані і складаються із сукупності обставин, що взаємодіють, до яких належать: особливості предмета злочинного посягання; антисуспільна установка особи злочиния та причини ї̈ формування; реальні життєві ситуації, які разом із внутрішніми якостями особи злочиния сприяли вчиненню даного виду злочинів. Зауважено, що дочільно визначити вплив на причини виникнення злочинів зазначеної категорії, а саме економічної ситуачії у країні, а також існування господарських та фінансових проблем. Крім економічних причин, що впливають на вчинення злочинів чієї категорії, існують і політичні причини. Із цьвого приводу можна відзначити політичну нестабільність в Украйні та загострену економічну та сощіальну ситуацію.

У статті підкреслено, що знання правоохоронними органами «слідової картини» викрадання природного газу, умов вчинення иих злочинів та умов охорони природного газу під час розслідування злочинів, пов'язаних із його викраденням шляхом маніпулячій із лічильниками, дозволить оминути окремі слідчі помилки, допоможе покрашенню діяльності органів досудового слідства в боротьбі із вказаними злочинами. Крім того, для проведення криміналістичного аналізу «слідової картини» викрадень природного газу шляхом втручання в роботу приладів обліку, поряд з іншими елементами криміналістичної характеристики злочинів, істотне значення мають також дані про особу злочиния.

Ключові слова: зміна середовища, процес злочину, інформація про наявність злочину, класифікація слідів, особливості предмета злочинного посягання, умови та причини вчинення злочину.

Постановка проблеми. Кожний злочин неминуче супроводжується виникненням «слідової картини». Ці відображення виявляються певними змінами середовища. Існує певна пов'язаність процесу злочину 3 іншими процесами реальності. Процес злочину викликає зміни середовища, а вони інформують нас про наявність злочину [13, c. 75].

Поняття «слідова картина» містить дві складові частини:

1) слід, який має чотири значення (відбиток, відтиск чого-небудь на землі або іншій поверхні; залишок або ознака чого-небудь; наслідок чого-небудь; нижня частина підошви ноги [25, с. 258]);
2) картина, під якою розуміють те, що можна бачити, уявляти собі в конкретних образах [22, с. 44].

Тобто за змістом «слідова картина» - це поєднання джерела та інформації, що відображається ним.

Аналіз досліджень і публікацій із даної теми. Терміном «слідова картина» вперше у криміналістичній науці скористався М. В. Салтевський. Він зазначав, що «слідова картина» у широкому їі значенні виникає внаслідок вчинення злочину і є одним 3 елементів криміналістичної характеристики злочинів [19, с. 14].

Окрім того, М. В. Салтевський, порівнюючи деталі криміналістичних характеристик 
злочинів, які запропонували вчені-криміналісти І. Ф. Герасимов, Р. С. Бєлкін, О. Н. Колесніченко, М. О. Селіванов, В. Г. Танасевич, О. М. Васильєв, О. Г. Філіппов та ін., прийшов до висновку, що такі елементи, як типові ситуації вчинення злочину (час, місце, умови) і типові матеріальні сліди та їх місцезнаходження досить близькі за змістом і можуть бути об'єднані.

Умови, час і місце вчинення злочину стають відомими тільки після «прочитання» «слідової картини», тобто після збору первинної інформації. Саме сліди надають інформацію про місце, час та інші обставини події злочину. Тому «слідова картина», тобто речові обставини й уявні відбитки в пам'яті, $€$ важливим елементом криміналістичної характеристики [19, с. 15].

Взагалі існує кілька точок зору на розуміння поняття «слідова картина».

Уперше дефініцію сліду запропонував I. M. Якимов, який вважав слідом відбиток на будь-якому предметі, що дає можливість судити про його форму чи призначення [28, с. 44].

На думку ж Е. Анушат, слідом є все те, що криміналіст може сприйняти і якимось чином криміналістично скористатися [1].

А. Мерген різнив сліди речові (відбитки, плями тощо) і психічні (переживання жертви, злочинця тощо) [2].

Іншої точки зору дотримувались такі науковці, як С. М. Потапов [17], М. Г. Богатирьов [4], Г. Л. Грановський [8], І. Ф. Крилов [14], Л. К. Литвиненко [15, с. 97], М. А. Селіванов [21, с. 179], А. І. Вінберг [5, с. 174], Б. І. Шевченко [26, с. 13], які вважали сліди будь-якими матеріально фіксованими змінами середовища.

Згідно із цією точкою зору сліди необхідно ділити на:

1) сліди у вузькому розумінні (відбивають зовнішню будову об'єктів, які взаємодіють);

2) у широкому розумінні (які виникають у результаті взаємодії суб'єктів злочину з об'єктами матеріального). На думку названих вчених, ці сліди можуть бути двох видів: матеріальні (відбитки на предметах, переміна обстановки події) та ідеальні (джерела мовної інформації)

С. М. Потапов вважав, що сліди є «відображенням на матеріальних предметах ознак явищ, причинно пов'язаних із подією, що розслідується». Сліди, на думку вченого, можуть виникати від людей, окремих предметів і від дій сил природи» [17].

Формування цілей статті. Завданням статті є вивчення і аналіз поняття «слідова картина» та опис типової «слідової картини» викрадання природного газу шляхом втручання в роботу приладів обліку.
Виклад основного матеріалу. Знання типізованих для певних категорій злочинів слідів та їхніх носіїв служать базисом для формулювання напрямів та методів пошуку реальних слідів, способів їх виявлення, вилучення, виявлення та використовування інформації, що в них міститься.

Сьогодні криміналістика пішла напрямом дослідження слідів у вузькому розумінні, оскільки це вкладається в основне завдання трасології - ідентифікації об'єкта, який залишив слід.

Ми згідні з позицією Р. С. Бєлкіна, який відмічав, що поняття «сліди в широкому розумінні» і «сліди у вузькому розумінні», що практично нічого не показують, потрібно виключити 3 мови юриспруденції та замінити на терміни «сліди злочину» та «сліди відображення» [3, с. 57].

Сліди класифікуються за різними критеріями. Згідно $з$ вивченими нами справами про викрадення природного газу шляхом маніпуляцій із лічильниками вважаємо доцільним розділити сліди злочинів досліджуваної категорії за способом їх вчинення на декілька груп:

1) сліди зміни схеми включення приладу обліку природного газу (відсутність або порушення пломби на приладі обліку природного газу; відсутність чи порушення пломби на клемній кришці приладу обліку природного газу і т. д.);

2) сліди зміни нормованої похибки приладу обліку природного газу (уповільнене обертання диска приладу обліку природного газу за рахунок збільшення гальмівного моменту приладу; відсутність чи порушення пломби приладу обліку природного газу; порушення пломби приладу обліку; наявність подряпин, слідів механічного впливу на шестірнях рахункового механізму і т.п.);

3) сліди пошкодження приладу обліку природного газу (наявність у механізмі приладу обліку природного газу споживача бруду; пошкодження оглядового скла приладу обліку природного газу споживача; наявність просвердленого отвору в кожусі приладу обліку природного газу споживача; наявність подряпин на диску приладу обліку природного газу споживача навпроти отвору; наявність просвердленого отвору в цоколі приладу обліку природного газу споживача і т. п.).

На думку вітчизняних вчених та практиків, до числа основних криміналістично значущих ознак «слідової картини» злочинів категорії, яка розглядається, слід віднести умови їх вчинення [20; 24, с. 21].

Умови як складова частина злочину є найменш дослідженою частиною «слідової картини». Проте в окремих криміналістичних 
методиках вони згадувалися ще до першого використання терміна «криміналістична характеристика злочинів».

Науковці С. О. Голунський [7, с. 25], В. І. Громов [9, с. 49] та Б. М. Шавер [10, с. 29], окрім місця та часу вчинення злочину, до «слідової картини» відносили також умови однак не конкретизували їх.

Також умови вчинення злочину досліджували І. Ф. Герасимов [6, с. 330], О. Н. Колесніченко та В. О. Коновалова [12, с. 41], В. О. Образцов, М. П. Яблоков [27] та ін. [23, с. 36$]$.

Злочини, які ми досліджуємо, як і всі людські вчинки, є наслідком взаємодії індивідуальних якостей людей і об’єктивної ситуації. Саме тому причини та умови цих соціальних явищ варто шукати в обставинах реального життя.

Ми підтримуємо позицію Р. С. Бєлкіна, що в наявних переліках елементів криміналістичної характеристики відсутні вказівки на опис типових для даного виду злочинів причин і умов, які сприяють його вчиненню [3, с. 315], та вважаємо, що для криміналістичної характеристики викрадення природного газу шляхом маніпуляцій із лічильником встановлення типових причин і умов, які сприяють їх вчиненню, має велике значення.

Причини та умови викрадення природного газу шляхом втручання в роботу приладу обліку тісно пов'язані і складаються із сукупності обставин, що взаємодіють, до яких належать: особливості предмета злочинного посягання; антисуспільна установка особи злочинця та причини її формування; реальні життєві ситуації, які разом із внутрішніми якостями особи злочинця сприяли вчиненню даного виду злочинів.

Розглядаючи вищезазначені обставини, доцільно, на нашу думку, визначити вплив економічної ситуації у країні, а також господарські та фінансові умови. Крім економічних причин, що впливають на вчинення злочинів зазначеної категорії, є, як вказує наше дослідження, і політичні причини.

Із цього приводу можна відзначити політичну нестабільність в Україні та загострену економічну та соціальну ситуацію.

Знання слідів, типових для даної категорій злочинів, служить основою для визначення напрямків і методів пошуку реальних слідів, використання засобів для їх виявлення, вилучення та використання інформації 3 метою глибокого та неупередженого розслідування кримінальної справи.

Для проведення криміналістичного аналізу слідової картини викрадення природного газу шляхом маніпуляцій із приладами обліку разом з іншими елементами криміна- лістичної характеристики злочинів визначальне значення мають дані про умови охорони природного газу.

Президент України Петро Порошенко 9 квітня 2015 року підписав Закон «Про ринок природного газу» [11].

Закон розкриває правові засади функціонування ринку природного газу України та має на меті закласти плідне конкурентне середовище на ринку природного газу 3 урахуванням основних вимог законодавства Свропейського союзу [11].

Закон «Про ринок природного газу» фіксує встановлені в Свросоюзі економічно обгрунтовані підходи до організації роботи газового ринку та має на меті відокремлення функцій оператора від функцій видобувників та постачальників, чітке окреслення функцій держави та незалежність регулятора, а також вільне ціноутворення [18].

Законопроект був розроблений Міністерством енергетики та вугільної промисловості України спільно з Національною комісією, яка виконує державне регулювання у сферах електроенергетики та комунальних послуг, та Національною акціонерною компанією «Нафтогаз України» на виконання державної політики імплементації Угоди про асоціацію між Україною та СС.

Згідно з документом ринок природного газу діє на засадах вільної добросовісної конкуренції, за винятком діяльності суб'єктів природних монополій, та на принципах високого рівня захисту прав та інтересів споживачів природного газу, забезпечення першочергового питання безпеки постачання природного газу; вільного вибору постачальника природного газу; рівноправності ввезення та вивезення природного газу на територію України; нейтралітету держави в питаннях функціонування ринку.

Постачання природного газу відбувається за цінами, що вільно встановлюються між постачальником та споживачем, за винятком випадків, передбачених цим законом.

Оператор газорозподільної системи відповідає за надійну та безпечну експлуатацію, підтримання в належному стані та розвиток газорозподільної системи, якою він користується на законних засадах.

Президентом України 27 серпня 2014 року була створена Національна комісія, що здійснює державне регулювання у сферах енергетики та комунальних послуг (НКРЕКП). НКРЕКП - незалежний державний колегіальний орган, метою діяльності якого є державне регулювання, моніторинг та контроль за діяльністю суб'єктів господарювання у сферах енергетики та комунальних послуг. 
Комісія утворена з метою виконання Законів України «Про природні монополії», «Про електроенергетику» і «Про державне регулювання у сфері комунальних послуг».

Основними завданнями Національної комісії, що здійснює державне регулювання у сферах енергетики та комунальних послуг, є:

1. Комісія здійснює державне регулювання з метою досягнення балансу інтересів споживачів, суб'єктів господарювання, що провадять діяльність у сферах енергетики та комунальних послуг, і держави, забезпечення енергетичної безпеки, європейської інтеграції ринків електричної енергії та природного газу України.

2. Комісія здійснює державне регулювання шляхом:

1) нормативно-правового регулювання у випадках, коли відповідні повноваження надані НКРЕКП законом;

2) ліцензування діяльності у сферах енергетики та комунальних послуг;

3) формування цінової і тарифної політики у сферах енергетики та комунальних послуг та реалізації відповідної політики у випадках, коли такі повноваження надані НКРЕКП законом;

4) державного контролю та застосування заходів впливу;

5) використання інших засобів, передбачених законом.

3. Основними завданнями Комісії є:

1) забезпечення ефективного функціонування та розвитку ринків у сферах енергетики та комунальних послуг;

2) сприяння ефективному відкриттю ринків у сферах енергетики та комунальних послуг для всіх споживачів і постачальників та забезпечення недискримінаційного доступу користувачів до мереж/трубопроводів;

3) сприяння інтеграції ринків електричної енергії, природного газу України з відповідними ринками інших держав, зокрема в рамках Енергетичного Співтовариства, співпраці з Радою регуляторів Енергетичного Співтовариства, Секретаріатом Енергетичного Співтовариства та національними регуляторами енергетики інших держав;

4) забезпечення захисту прав споживачів товарів, послуг у сферах енергетики та комунальних послуг щодо отримання цих товарів і послуг належної якості в достатній кількості за обгрунтованими цінами;

5) сприяння транскордонній торгівлі електричною енергією та природним газом, забезпечення інвестиційної привабливості для розвитку інфраструктури;

6) реалізація цінової і тарифної політики у сферах енергетики та комунальних послуг;
7) сприяння в впровадженню заходів 3 енергоефективності, збільшенню частки виробництва енергії з відновлюваних джерел енергії та захисту навколишнього природного середовища;

8) створення сприятливих умов для залучення інвестицій у розвиток ринків у сферах енергетики та комунальних послуг;

9) сприяння розвитку конкуренції на ринках у сферах енергетики та комунальних послуг;

10) інші завдання, передбачені законом [16]

Крім того, Кодексом газорозподільних систем передбачено відповідальність споживача природного газу за викрадення природного газу в разі споживання природного газу без приладів обліку, пошкодження приладу обліку згідно зі ст. 103-1 Кодексу України про адміністративні правопорушення України і ст. 188-1 КК України, якими передбачені адміністративна і кримінальна відповідальність за викрадення природного газу шляхом його самовільного використання

\section{Висновки}

Викрадення природного газу, яке відбувається 3 різних причин, як то недостатній рівень заробітної платні, пенсій, затримки 3 їх виплатою і т.п., $є$ однією 3 основних причин зростання втрат природного газу в газових мережах. Викрадення природного газу - це фінансові втрати газопостачальної організації.

Узагальнюючи наведене, відзначимо, що знання правоохоронними органами «слідової картини» викрадання природного газу, умов вчинення цих злочинів та умов охорони природного газу під час розслідування злочинів, пов'язаних із його викраденням шляхом маніпуляцій із лічильниками, дозволить минути окремих слідчих помилок, допоможе покращенню діяльності органів досудового слідства в боротьбі із вказаними злочинами.

Крім того, для проведення криміналістичного аналізу «слідової картини» викрадень природного газу шляхом втручання в роботу приладів обліку поряд 3 іншими елементами криміналістичної характеристики злочинів істотне значення мають також дані про особу злочинця.

\section{Список використаних джерел:}

1. Anushat E. Kriminalische Spurenkunde. Berlin, 1943.

2. Mergen A. Die Wissenschaft vom Verbrechen Eine Einfuhrung in die Kriminologie. Hamburg, 1961

3. Белкин Р.С. Курс криминалистики: в 3 т. Т. 3: Криминалистические средства, приемы и рекомендации. Москва : Юристъ, 1997. 478 с. 
4. Богатырев М.Г. О транспортной трассологии, ее предмете, системе. Рефераты докладов 2-й научной конферениии Ташкентского НИИСЭ. Ташкент, 1964.

5. Винберг А.И. Криминалистическая экспертиза в советском уголовном процессе. Москва : Госюриздат, $1956.220 \mathrm{c}$.

6. Герасимов И.Ф. Общие положения методики расследования пре ступлений. Криминалистика: учебник / под ред. И.Ф. Герасимова, Л.Я. Драпкина. Москва, 1994.

7. Голунский С.А. Криминалистика. Методика расследования отдельных видов преступлений. Москва, 1939. 252 с.

8. Грановский Г.Л. Основы трассологии (общая часть). Харьков : Харьковский НИИСЭ, 1965. 123 с.

9. Громов В. Методика расследования преступлений. Руководство для органов милиции и уголовного розыска. Москва : Сов. законодательство, 1929. 149 с

10. Евгеньев М.Е. Методика и техника расследования преступлений. Москва, 1940.

11. Закон України «Про ринок природного газу» від 09.04.2015 № 329-VIII. URL: http:// zakon2.rada.gov.ua/laws/show/329-19/page.

12. Колесниченко А.Н. Криминалистическая характеристика преступлений: учебное пособие. Харьков : Харьк. юрид. ин-т, 1985. 93 с.

13. Кримінально-процесуальні та криміналістичні прийоми і засоби протидії злочинній діяльності : монографія / С.В. Євдокіменко, Я.В. Кузьмічов, В.В. Семенов, С.В. Хільченко. Київ : ПАЛИВОДА А.В., 2006. 352 с.

14. Крылов И.Ф. Следы на месте преступления. Ленинград : Изд-во ЛГУ, 1961. 132 с.

15. Литвиненко Л.К. Понятие и классификация следов в трассологии. Материаль 3-й научной конферениии, посвященной памяти М.И. Райского. Киев, 1958.
16. Основні завдання та функції національної комісії, що здійснює державне регулювання у сферах енергетики та комунальних послуг. URL : http://www.nerc.gov.ua/?id=11804.

17. Потапов С.M. Принципы криминалистической идентификации. Советское государство и право. 1940. № 1.

18. Ринок газу в Україні адаптували до законів Євросоюзу. URL : https://radako.com.ua/news/rinokgazu-v-ukrayini-adaptuvali-do-zakoniv-ievrosoyuzu.

19. Салтевский М.В. О структуре криминалистической характеристики хулиганства и типичных следственных ситуациях. Криминалистика и судебная экспертиза. 1982. Вып. 25.

20. Салтевський М.В. Криміналістика : навч.довід. посіб. Київ : Правник, 1996. 159 с.

21. Селиванов Н.А. Общие сведения о следах. Криминалистическая техника. Москва, 1959.

22. Словарь русского языка. Т. 2. Москва : Русский язык, 1958. 736 с

23. Советская криминалистика. Методика расследования отдельных видов преступлений / В.К. Лисиченко, В.И. Гончаренко, М.В. Салтевский и др. ; под ред. В.К. Лисиченко. Київ : Вища школа, 1988. 406 с.

24. Старушкевич А.В. Криміналістична характеристика злочинів : навч. посіб. Київ : Правник, 1997. $41 \mathrm{c}$

25. Толковый словарь русского языка / под ред. Д.Н. Ушакова. Т. 4. Москва : Русский язык, $1940.632 \mathrm{c}$.

26. Шевченко Б.И. Научные основы современной трасологии. Москва : Госюриздат, 1947.73 с.

27. Яблоков Н.П. Обстановка совершения преступления как элемент его криминалистической характеристики. Криминалистическая характеристика преступлений. Москва, 1984.

28. Якимов И.Н. Осмотр. Москва : Госюриздат, 1935 .

The term "trace picture" is analyzed in this article. This concept is closely related to the crime commitment. We can see, learn and analyze trace picture after the committing certain crime. There are many different points of view on the understanding the concept "trace picture".

The knowledge of types for singing categories of negligence and that of noses serves as a basis for formulating direct methods and methods of real-life methods, of which they can be manifested, learned, and more often.

The annual crime statistics was sent directly to the university at the same time.

The article deals with the study and analysis of the notion "trace picture" and description of typical trace picture after the abduction of natural gas by interfering with accounting devices work.

The study has revealed that crime traces are classified according to different criteria, which are characterized in the article. The author discusses the essence of the criminological traces of the abduction of natural gas by interfering with accounting devices work and divides them into specific groups by the method of committing this crime. The causes and conditions of the abduction of natural gas by interfering with accounting devices work consist of the following: peculiarities of the subject of criminal assault, antisocial identity of the offender and the reasons for their formation; real life situation and the internal qualities of the offender which facilitated the commission of this type of crime. A special attention is paid to the economic and political causes of these crimes.

The author concludes that study and analysis of the trace picture of the abduction of natural gas by interfering with accounting devices work will help the police to investigate crimes, connected with the abduction of natural gas by different magipulation with counters, will allow to avoid individual professional mistakes, will improve the activities of the pre-trial authorities in the fight against crimes connected with the abduction of natural gas. In addition, in order to conduct a criminal analysis of the "trace picture" of natural gas with a hand, we'll put the robot in the right position in the robot, the order of the most important elements of the criminal characteristic is important.

Key words: environment, process of crime, trace classification, peculiarities of the subject of criminal assault, abduction of natural gas, crime commitment, causes and conditions of the crime. 